\title{
Vaticinium de coniunctione Liliorum cum Aquila. The prophecy from Prognosticatio... of Johann Lichtenberger and its interpretation for Henri de Valois (1575)
}

After the flight of Henri de Valois from Cracow in June 1574, there were some people who did not accept this to be the end of the reign of the French king on the Polish throne. The Catholic milieu, centred around Jakub Uchański and Stanisław Karnkowski, strived actively for convincing Henri to retain power in Poland. In summer 1574, one of the most fervent Henri's supporters, Jan Dymitr Solikowski, set off to France. His aim was to persuade Henri that he should not renounce the Polish crown and that he can rule the distant kingdom when staying in France.

Solikowski presented his arguments in a much discussed ${ }^{1}$ text Probi et Galliae ac Poloniae amantis viri, ad Gallos et Sarmatos oratio ${ }^{2}$ - a fiery oration evoking similarities between the two nations and extolling benefits of their union under one ruler. The oration has been published anonymously ${ }^{3}$ in

1 On the writings of Solikowski related to the election of Henri, see J. Nowak-Dłużewski, Okolicznościowa poezja polityczna w Polsce. Pierwsi królowie elekcyjni, Warsaw, 1969, pp. 53-56; E. Kotarski, Publicystyka Jana Dymitra Solikowskiego, Toruń, 1970, pp. 24-26, 111-14; M. Serwański, Henryk III Walezy w Polsce. Stosunki polsko-francuskie $w$ latach 1566-1576, Cracow, 1973, pp. 213-14.

2 Probi et Galliae ac Poloniae amantis viri, ad Gallos et Sarmatas oratio. Accessit insigne et pervetus vaticinium de liliorum et aquilae septemtrionalis conjunctione, Basel, 1575.

3 Solikowski himself wrote about the authorship of the oration: Extat hoc nomine Oratio Basileae impressa, sub titulo 'Probi et Galliae ac Poloniae amantis viri', utilis, plena 
Basel in $1575^{4}$ and attached to it was the text (announced already in its subtitle) of Vaticinium de coniunctione Liliorum cum Aquila, desumptum ex antiquis praedictionibus Ioannis Lichtembergii, quod adscribit D. Brigitae Sveciae Reginae. ${ }^{5}$ This part was omitted in all later reprints of Probi et Galliae [...] oratio, ${ }^{6}$ as well as in discussions on Solikowski's political writings. An old prophecy that is contained therein, as well as its topical interpretation, seem to be a much more interesting argument to persuade Henri to keep the Polish crown, than any disquisition on the Polish-French friendship. In the days when Adieu à la Pologne enjoyed a considerable popularity in France, the grandiloquent Solikowski's words could have been received with a kind indifference at the best. It is by referring to old prophecies, especially those predicting great successes for the French king, he could arise much more interest at the court and in humanist circles. In a chapter entitled Vaticinium de coniunctione..., Solikowski included a text taken from Prognosticatio in Latino (Heidelberg, 1488) by Johann Lichtenberger (ob. 1503), the court astrologer of the emperor Frederick

consilii (J.D. Solikowski, Commentarius brevis rerum polonicarum a morte Sigismundi Augusti Poloniae Regis, Gdańsk, 1647, Georg Förstrer, p. 35). Considering the fact that Solikowski mentions (in Commentarius brevis...) his text published in 1574 in Paris, Karol Estreicher assumed that the French translation of the Latin oration has been published first, as Discours d'un Polonois catholique sur la fuyte de Henry de Valois troisiesme, hors du Royaume de Polongne, by the printing house of André le Coq in 1574 (preserved in the Bibliothèque Nationale in Paris). The publication was commonly considered lost and 'waiting to be discovered' (Kotarski, op. cit., pp. 107-08). In Paris libraries there are five copies of a book with that title, all of them printed in 1589: three by André le Coq (Bibliothèque de l'Arsenal, 8-H-6425 (9) and 8-H-12795 (1); Bibliothèque Nationale de France, 8-LB34-58 (A)), two by Pierre des-Haye (Bibliothèque de l'Arsenal, 8-H-12729 (6); Bibliothèque Nationale de France, 8-LB34-58). They contain a short report on the election, the stay of the Polish envoys in Paris in autumn 1573, Henri's stay in Cracow and his flight from Poland. In all these copies the text ends at page 12, followed by three occasional poems. That work is not a translation of Solikowski's oration.

4 Cf. M. Włodarski, Polsko-bazylejskie więzi kulturalne i literackie w XVI wieku, Cracow, 1987, p. 123. See also, P.G. Bietenholz, Basle and France in the Sixteenth Century. The Basle Humanists and Printers in Their Contacts with Francophone, Geneva, 1971.

5 Probi et Galliae ac Poloniae..., op. cit., 1. 24r-27v. See Appendix.

6 Cf. M. Cromer, Polonia, sive de Origine et rebus gestis Polonorum libri XXX, Cologne, 1589, Off. Birckmannica, pp. 721-31; Pisma polityczne z czasów pierwszego bezkrólewia, ed. by J. Czubek, Cracow, 1906, pp. 596-613. 
III. ${ }^{7}$ The compilation work, ${ }^{8}$ combining 'Arab astrology with Joachimian prophecies, calculations and fortune-telling' as devoted to future fates of the Pope and Church, of the Emperor and the empire, laypeople, Turks and Jews. The astrological and political treatise turned out to be extremely successful. It was repeatedly reprinted and enjoyed an enormous popularity for almost a century, especially in German-speaking countries and in Italy. Lichtenberger, deeply convinced of the impending end of times, ${ }^{10}$ discussed in Prognosticatio... the most popular of the prophetic themes - that of the Last Ruler of the World, ${ }^{11}$ known from the Apocalypse of Pseudo-Methodius ${ }^{12}$ and the prophecy of the Tiburtine Sibyl. ${ }^{13}$ The text describes a king who will defeat Arabs thus initiating a period of peace and prosperity. Then Gog and Magog will come, and after ten years and half of the king's reign, the Antichrist will turn up. At that time, the king will lay his crown on the Golgotha and he will die, leaving the fight with the Antichrist to higher powers. ${ }^{14}$

7 D. Kurze, 'Johannes Lichtenberger. Leben und Werk eines spätmittelalterlichen Propheten und Astrologen', Archiv für Kulturgeschichte, 38, 1956, pp. 328-43; idem, Johannes Lichtenberger. Eine Studie zur Geschichte der Prophetie und Astrologie, Lübeck and Hamburg, 1960; idem, 'Popular Astrology and Prophecy in the Fifteenth to Sixteenth Centuries: Johannes Lichtenberger', in 'Astrologi Hallucinati. Stars and the End of the World in Luther's Time, ed. by P. Zambelli, Berlin and New York, 1986, pp. 177-93.

8 The main sources used by Lichtenberger were: a work by Paulus of Middelburg Prognostica (being in a great measure an adaptation of works of Albumasar), Tractatus de cometis by Konrad Heingarter, Liber Concordie by Joachim of Fiore, works of pseudo-Joachim (Super Hieremiam, Oraculum Cyrilli, Vaticinium Sybillae Erithrea), Telesfor of Cosenza, Reinhard Lollard, and St Bridget. For a more extensive discussion on this subject, see D. Kurze, 'Prophecy and History. Lichtenberger's Forecast of Events to Come from the Fifteenth to Twentieth Century. Their Reception and Diffusion', Journal of the Warburg and Courtauld Institutes, 21, 1958, p. 64; M. Reeves, The Influence of Prophecy in the Later Middle Ages. A Study in Joachimism, Oxford, 1969, p. 348.

9 Kurze, 'Prophecy and History...', op. cit., p. 64.

10 Cf. Reeves, The Influence of Prophecy..., op. cit., p. 351.

11 Cf. idem, 'Joachimist Influences on the Idea of A Last World Emperor', Traditio. Studies in Ancient and Medieval History, Thought and Religion, 17, 1961, pp. 323-70. 12 P.J. Alexander, 'The Medieval Legend of the Last Roman Emperor and Its Messianic Origin', Journal of the Warburg and Courtauld Institutes, 41, 1978, pp. 1-15.

13 M. Rangheri, 'La "Epistola ad Gerbegam Reginam de Ortu et Tempore Antichrist" di Adsone de Montier-en-Der e le sue fonti', Studi Medievali, 14, 1973, pp. 708-12.

14 Cf. Reeves, The Influence of Prophecy..., op. cit., pp. 300-03. 
When Lichtenberger started to work on the treatise, he viewed Frederick III as the Last Ruler of the World. When these expectations did not come true, the astrologer turned his hopes towards Maximilian I. ${ }^{15}$ The author of Prognosticatio... believed that it is an alliance of France and Germany, an union of the Lily and the Eagle, that will bring about the end of times. He took the concept of the union of the Lily and the Eagle from a popular prophecy attributed to St Bridget, ${ }^{16}$ and he added it to Chapters 17 and 18 in the second volume of his book. ${ }^{17}$ It was the text of those chapters that Solikowski included in his oration.

The text of Vaticinium... is preceded by a wood engraving that depicts a cloud with a hand emerging from it, holding a pennant. ${ }^{18}$ On the pennant there are three French lilies and a crowned eagle in the form known from the Polish coat of arms. The iconography of the engraving was taken from the work of Lichtenberger. ${ }^{19}$ Prognosticatio... was an illustrated book, enriched with forty-five wood engravings. According to Dietrich Kurze, the engravings were intended not only to illustrate the text, but also to remind the eidetic sources of the prophecy. Paracelsus described such representations as 'magic figures', pointing out that their function is equally prophetic as is the text itself. ${ }^{20}$ The engraving included

15 Cf. ibid., p. 347, 350-53.

16 Prophecies attributed to St Bridget have been published already during her lifetime in seven volumes of Liber coelestis revelationum. Basing on fragments of them, Johannes Tortsch from Leipzig compiled around 1433 a short work Onus mundi, being the most popular source for the prophecies of the saint (ibid., p. 338).

17 Johannes Lichtenberger, Pronosticatio in Latino. Rara et prius non audita que exponit et declarat non nullos celi influxus et inclinationem certarum constellacionum magne videlicet coniunctionis et eclipsis quae fuerant istis annis, Heidelberg, 1488, Knoblochtzer, 1. C VIIr - D Iv.

18 http://gallica.bnf.fr/ark:/12148/bpt6k794627.zoom.f47 [accessed 30.05.2009], see also, Reeves, 'Joachimist Influences...', op. cit., s. 341-46.

19 The first edition of Prognosticatio..., published in Heidelberg in 1488: http:// diglib.hab.de/inkunabeln/1-quod-3/start.htm?image=00034 [accessed 30.05.2009]. Solikowski consulted, most probably, a later edition, cf. an engraving in a copy of Prognosticatio... printed in Cologne in 1526: http://mdz10.bib-bvb.de/ - db/0002/ bsb00024788/images/index.html?seite=59 [accessed 30.05.2009].

20 Cf. Kurze, 'Popular Astrology...', op. cit., p. 187. See also, B. Baert, 'Iconographical notes to the Prognosticatio of Johannes Lichtenberger (1488), Using an Edition Printed by Peter Quentel (1526)', in Early Sixteenth Century Printed Books (1501-1540) in the Library of the Leuven Faculty of Theology, ed. by F. Gistelinck and M. Sabbe, Leuven, 1994, pp. 139-68, esp. p. 143. 
in Vaticinium... from 1575 differs slightly from its German prototypes. In all editions, a half of a black eagle is depicted, with its head bent markedly to the left, which suggested the two-headed eagle of the Holy Roman Empire, introduced in that form by Sigismund of Luxemburg.

The Polish eagle instead of the German one on the engraving in Oratio... is a harbinger of the book's contents. Lichtenberger's prophecy is followed by its Explicatio...: the famous astrologer, basing on the revelation of St Bridget, rightly predicted the fortunate alliance of the Lily and the Eagle, which means France and Poland. The consecutive sentences of the prophecy and their Polish-French meaning are presented in the limpid form of a table. The interpretation is not surprising: the appearance of the Lily in the West came true through the election of Henri de Valois as the Polish king, and such expressions as 'Aquila Orientalis' (fr. L) or 'Terra Virginalis' stand - according to Solikowski - for Poland. The most important part of the prophecy, 'Nam de bono Gallo antique prophetia invenitur, ad eum modum. Aquilae grandi sociabitur Lilium ab Occidente in Orientem et movebitur contra leonem' (fr. G) is crucial also for its 'Polish' interpretation: the Lily united with the Eagle will be transferred to the East, where it will oppose the Lion. The Lion stands - according to Explicatio... - for Turkey, thus Henri, as the king of Poland and France, will fight against the Ottoman Empire. According to Lichtenberger's text, the Lion will be betrayed by the Lily (fr. $\mathrm{H}$ ). Next, when commenting on the sentence 'Flagrabit lilium in Alemania, unde laus eius suprema volabit sub Aquila' (fr. I), Solikowski criticises the traditional identification of the Eagle with Germany. It is the alliance of Poland and France, led by Henri, that will secure the victory for Christendom (fr. K, M, N). This idea concludes the text of Vaticinium...

Prophetic texts, by definition obscure and symbolic, could have been easily adapted to any momentary needs. In the case of Solikowski's Explicatio... the result was surprisingly good. He succeeded in interpreting a chosen fragment of one of the most important prophecies - acknowledged through the authority of St Bridget and disseminated through the work of Lichtenberger. He did it without manipulating the text, which was a common practice, for example, by quoting sentences without their context or omitting inconvenient fragments. To give an example related to Solikowski's prophecy: this is how Jean Lemaire de Belges, in his Traité de la schisme (1511) promoting the cooperation between France and Germany, 
quoted a sentence from Prognosticatio...: 'Aquile grandi sociabitur lilium, et movebitur ab occidente in orientem contra leonem. Leo carebit auxilio, etc.' As noticed by Jennifer Britell, Lemaire de Belges omitted the further part of the prophecy (where the Eagle is favoured) for the sake of Louis XII, being the addressee of the treatise. ${ }^{21}$ To adjust Vaticinium... to the current political situation, it was sometimes necessary to use elaborate arguments, as it was, for example, in a commentary by Wolfgang Aytinger, who, in 1496, reprinted Lichtenberger's treatise claiming it to be the text of Pseudo-Methodius' prophecy. According to Aytinger, in the sentence 'Egrediet lilium ex agro occidentali et erit crescens in mille millia in terra virginali' the Lily means Charles VIII, while 'terra Virginalis' stands for Sicily, lying under the Virgo constellation. Thus the prophecy has been fulfilled in 1495, when the French king captured Naples. ${ }^{22}$

The text of the prophecy was particularly favourable to Solikowski's intentions. Chosing the lucid form of a table, he proposed an interpretation for each sentence in the whole two chapters of Lichtenberger's work; this must have appeared unusually credible. Thus Explicatio... of the old prophecy was a spectacular argument in Solikowski's political campaign aimed at convincing Henri de Valois to keep the Polish crown. In accordance with a common practice, Vaticinium... was used as a tool in the current political game. In spite of appearances, prophecies did never reach far into the future. On the contrary - they concerned mainly current events, like the papal or imperial elections. The prophetic tradition, wrote Jacques Halbronn, 'has an answer to everything; it provides ad hoc a text for any circumstance. ${ }^{23}$ Apart from the union of Poland and France under a single ruler, as advocated by Solikowski, Explicatio... raises another issue that was urgent at that time, and namely the Turkish problem $^{24}$ that - as it turned out - aroused the most intense interest among Solikowski's audience.

21 Cf. J. Britnell, 'Jean Lemaire de Belges and Prophecy', Journal of the Warburg and Courtauld Institutes, 42, 1979, p. 160.

22 Cf. R. W. Scheller, 'The Imperial Themes in Art and Literature of the Early French Renaissance. The Period of Charles VIII', Simiolus. Netherlands Quarterly for the History of Art, 12, 1981-82, p. 54.

23 J. Halbronn, Mise en évidence d'une tradition prophétique occidentale. (Problèmes de méthodologie autour de la Pronosticatio de Lichtenberger), Centre Universitare de Recherche en Astrologie, http://cura.free.fr/decem/09halbr2.html [accessed 30.05.2009].

24 Cf. Serwański, op. cit., pp. 218-21, 233-38. 
Vaticinium... appealed without any doubt to tastes of the French court, where prophecies (and especially those predicting a glorious future for the rulers of France) were widely circulated and commented. ${ }^{25}$ For a long time, it was commonly assumed that Prognosticatio... gained no popularity in France. ${ }^{26}$ Actually, it was repeatedly reprinted since the late fifteenth century. Lichtenberger's prophecies were published without his name and with no illustrations, as a part of a book entitled Mirabilis liber. In 1522 a Latin-French edition has been published (then reprinted several times), prepared with the aim of supporting Francis' I candidacy to the imperial throne. ${ }^{27}$ Lichtenberger's prophecy appeared in France for the last time before the election of Henri in 1561, as a part of a collection entitled Recueil de prophéties et révélations. ${ }^{28}$ All those books displayed, naturally, a French bias, being intended to support the monarchy in decisive or difficult moments, like, for example, the defeat in the battle of Pavia. ${ }^{29}$ Halbronn associates the publication of the French translations of Mirabilis liber in 1525, 1561, and 1611 with the regencies, respectively of Louise of Savoy, Catherine de' Medici, and Marie de' Medici. ${ }^{30}$

In those troubled times, a significant popularity was gained by the prophecy attributed to St Bridget, that predicted a death on a battlefield for a victorious French king, and the reign over the East and the West for his mother. The contents of these prophecies, as well as the custom to use them for political purposes, were well known to Catherine de' Medici and her circle. ${ }^{31}$ Moreover, Mirabilis liber was probably the source of the most important prophetic text popular during the reign of the last

25 Cf. A. Y. Haran, Le lys et le globe. Messianisme dynastique et rêve impérial en France aux XVI et $X V I I^{e}$ siècles, Seyssel, 2000, pp. 105-40, esp. pp. 117-19.

26 Cf. Kurze, 'Prophecy and History...', op. cit., p. 67.

27 Cf. J. Britnell and D. Stubbs, 'The Mirabilis Liber. Its Compilation and Influence', Journal of the Warburg and Courtauld Institutes, 49, 1986, pp. 126. On the complex issue of the French edition of Prognosticatio..., see J. Halbronn, Mise en évidence..., op. cit.; idem, Astrologie et prophétie. Merveilles sans images, Paris, 1994, pp. 6-7.

28 The book contains the French translation of the prophecy of the Lily and the Eagle (La première partie du recueil des propheties et revelations, tant anciennes que modernes, Paris, 1561, Robert la Magnier, 1. 45v-47v).

29 Cf. Halbronn, Mise en évidence..., op. cit.

30 Cf. ibid.

31 Cf. G. Zarri, 'Les prophètes de cour dans l'Italie de la Renaissance', in Les textes prophétiques et la prophétie en Occident (XII $-X V I^{e}$ siècle), ed. by A. Vauchez, Rome, 1991, pp. 359-85. 
Valois, Livre merveilleux, ${ }^{32}$ associated with Guillaume Postel - a versatile scholar, theologian, orientalist, cabbalist and the prophet of a universal monarchy that would unite Jews, Christians and Muslims under the rule of a French king. ${ }^{33}$

A great admirer of Postel's thought was Claude du Pré3 ${ }^{34}$ - a lawyer based in Lyons, politician and, importantly, a close friend of Jan Dymitr Solikowski.

As can be learned from a letter sent from Lyons in October 1574, it was du Pré whom Solikowski asked for permission to consult the book of prophecies. ${ }^{35}$ In Abbregé fidelle de la vraye origine et genealogie des François (Lyons, 1601), du Pré mentions Lichtenberger's prophecy transmitted by the Polish scholar, ${ }^{36}$ quoting in extenso Chapters 17 and

32 The text has been written in 1551 and was circulated in manuscript form since the middle 1560's. Cf. F. A. Yates, Astraea. The Imperial Theme in the Sixteenth Century, London and Boston, 1975, pp. 125-46.

33 Cf. Reeves, 'Joachimist Influences...', op. cit., p. 381. For Postel, see W.J. Bouwsma, Concordia Mundi. The Career and Thought of Guillaume Postel, 1510-1581, Cambridge, 1957; F. Secret, Les Kabbalistes chrétiens de Renaissance, Paris, 1964, pp. 171-86; M. L. Kuntz, Guillaume Postel, Prophet of the Restitution of All Things. His Life and Thought, The Hague and London, 1981; Y. Petry, Gender, Kabbalah, and the Reformation. The Mystical Theology of Guillaume Postel (1510-1581), Leiden, 2004.

34 F. Secret, 'De quelques courants prophétiques et religieux sous le règne de Henri III', Revue de l'histoire des religions, 172, 1967, p. 31.

35 C. du Pré, Pratum, continens anthologiam epistolarum, orationum, sententiarum, apophtegmatum, aenigmatum, epitaphiorum et carminum, Paris, 1614, I. Libert, pp. 35-36: 'Fac me itaque certiorem e quo bibliopolio petenda sint exemplaria plura. Interim videbis praedictiones, quas ex variis locis desumpsi, an huic nostro seculo, aut alteri accommodari possint. Peto quoque hoc abs te ut ne tibi molestum sit, si tuam domum accessero, et libros tuos, quorum te magnam habere copiam intelligo, videro: quod quando tibi sit commodum, precor ut mihi significes'.

36 C. du Pré, Abbregé fidelle de la vraye origine et généalogie des François, Lyon, 1601, Thibauld Ancelin, 1. 106r-107r: 'Mais puisque nous sommes sur le discours des visions et propheties [...], il ne sera mal à propos d'escrire icy autre qui semble presager encore le retour et alliance des Rois François avec leur domination iusques en Orient, laquelle prophetie m'a esté baillée par un tres-scavant et eloquent Seigneur Iean de Soliskoski mon grand et singulier amy, qui avoit esté secretaire du feu Roy Sigismond de Pologne et vint en France l'an 1574 pour suivre le magnanime et vaillant Prince Henry III Roy de France et de Pologne, auquel il sembloit la vouloir accommoder: mais je ne diray rien si elle est de luy ou d'autre. Bien diray je en passant, que si les anciens ont adjousté foy à la prediction et oracle des faux Dieux, l'on peut mieux croire aux propheties des chrestiens, mesmement quand elles sont rapportées par autheurs approuvez. S'ensuit donc la prophetie de saincte Brigide Royne d'Escosse [sic!] tirée des predications du 
18 of Prognosticatio... Although du Pré mentions Solikowski's name and describes the circumstances under which his text was composed, he ignores the 'Polish' interpretation of Vaticinium... The commentary explaining St Bridget's vision as referring to the Polish-French alliance became outdated even before it was published. Early in the seventeenth century, the work of Solikowski aroused some interest because of its prediction of a victory over Turkey, and it was that explanation that was favoured by du Pré in Abbregé... and then in Pratum (1614).

Various prophecies foretelling the demise of Islam, and particularly Turkey being defeated by a universal monarch - the king of France, were among the most popular prophetic texts in sixteenth and seventeenth centuries. ${ }^{37}$ In 1574, Stefano Lusignano offered to Henri de Valois, then staying in Venice, a collection of prophecies foretelling 'come un Re di Francia debbia essere Imperatore Romano et distrugitor della setta de' Maometani. ${ }^{38}$ In this context, Solikowski's prophecy appeared again in 1611, reprinted in Recueil chrétien by G. de Bonnet. The work, dedicated to Marie de' Medici and predicting the conquest of the East by Louis XIII, consisted of various prophecies attributed to St Bridget. According to Bonnet, the most important among these was the prophecy of an erudite Polish noble, described by du Pré in Abbregé... In the dedication, Bonnet mentions that in the troubled times after the death of Henry IV a prediction of a French king ruling the East encouraged him and raised his hopes for the future. ${ }^{39}$ The French text of the prophecy (which has been quoted twice in the book, first after Abbregé... and then after Recueil de prophéties et révélations published in 1561) is accompanied by a commentary in the form of a poem with anagrams. From words and letters of the prophecy, Bonnet derives Louis' name, taking it as a harbinger of his glorious destiny. ${ }^{40}$

Seigneur jean de Liechtemberg Allemand, chapitres 17 et 18 lequel certes a faict de beaux recueils de propheties en son livre, que j'ay riere moy, mais par fortune en ces deux chapitre les feuillets se sont trouvez rompus et les au recouvert d'ailleurs'.

37 Cf. J. Deny, 'Les pseudo-prophéties concernant les Turcs au XVI' siècle', Revue des Études Islamiques, 10, 1936, pp. 201-20; P. Preto, Venezia e i Turchi, Florence, 1975, pp. 67-91; A.Y. Haran, op. cit., pp. 269-307.

38 Cf. S. Lusignano, Raccolta di cinque discorsi, intitolati corone, Padua, 1577, L. Pasquati; Secret, 'De quelques courants prophétiques...', op. cit., s. 29-32.

39 Cf. G. de Bonnet, Recueil chrétien, où sont une prophétie de sainte Brigide, reine d'Écosse, promettant au roi et aux chrétiens, par Sa Majesté, une grande prospérité et élévation, Paris, 1611, Pierre Chevalier, introduction, no p.

40 Cf. ibid., pp. 22-35. 
There is no doubt that Solikowski consulted Prognosticatio... during his stay in Lyons, as said by du Pré. Probably, however, it was not his first contact with the prophecies. The prophecies of the Lily were known also in Poland, gaining there some popularity during the first free election. Jan Januszowski wrote in Wróżki:

\begin{abstract}
Then, after the demise of Sigismund Augustus, the famous late king of Poland, if we elected Henri - the French king this day - as the Polish king [...] it was because of another prophecy about a lily in these words: Aquila a virgine fugata lilium excitabit, volabitque ad meridiem recuperando amissa. Hence they inferred that the monarch was destined for greatness. However, as the fate decreed otherwise, it was abandoned. ${ }^{41}$
\end{abstract}

It cannot be excluded, therefore, that Solikowski's idea to publish the prophecy of Lichtenberger was conceived still in Poland. He could have encountered with Prognosticatio... even earlier, during his studies in Wittenberg in 1559-60, ${ }^{42}$ when he met Philipp Melanchthon.

A letter to the German humanist is known, written by Jan Solikowski, the father of Jan Dymitr, expressing his gratitude for advices on his son's education. ${ }^{43}$ Melanchton, fascinated with comets, supernatural phenomena and mirabilia of all sorts, was an ardent adept of astrology. ${ }^{44}$

41 J. Januszowski, Wróżki Jana Podworzeckiego, Cracow, 1589, Drukarnia Łazarzowa, quoted after Staropolskie przepowiednie i mirabilia, ed. by J. Kroczek, Wrocław, 2007, p. 57. The prophecy in question comes also from Prognosticatio... (Lichtenberger, op. cit., l. B IIIr). See also, J. Kiliańczyk-Zięba, Czcionką i piórem. Jan Januszowski w roli pisarza i ttumacza, Cracow, 2007, pp. 214-19. Another political prophecy popular during the first interregnum was the so-called prognostyk Retyka, that contained a list of future Polish kings, cf. A.T. Klubiński, “Diversi color” - kariera przepowiedni elekcyjnej (1697-1764)', Barok, 5, 1996, 1 (9), s. 225-33.

42 Kotarski, op. cit., pp. 14-16. Concerning astrology in sixteenth century Wittenberg, see C. Brosseder, 'The Writing in the Wittenberg Sky: Astrology in Sixteenth-Century Germany', Journal of the History of Ideas, 66, 2005, pp. 557-76.

43 T. Wotschke, 'Zum Briefwechsel Melanchtons mit Polen', Archiv für Reformationgeschichte, 6, 1908-09, p. 353.

44 S. Caroti, 'Commettre, portenti, causalità naturale e escatologia in Filippo Melantone', in Scienze, credenze occulte, livelli di cultura, Florence, 1982, pp. 393-426; idem, 'Melanchthon's Astrology', in 'Astrologi Hallucinati'..., op. cit., pp. 109-21; D. Belucci, 'Melanchthon et la défense de l'astrologie', Bibliothèque d'Humanisme et Renaissance, 50 , 1988, pp. 587-622; Melanchthons Astrologie. Der Weg der Sternenwissenschaft zur Zeit von Humanismus und Reformation. (Katalog zur Ausstellung im Reformationsgeschichtlichen 
He expressed his admiration for Prognosticatio... of Lichtenberger in his extensive preface to the first edition of the famous Tractatus de Sphaera by Johannes de Sacrobosco (Wittenberg, 1531). ${ }^{45}$

One may expect that Solikowski's book could have been well received at the French court. The reminder of an old prophecy with its new explanation, and an illustration never before published in France and invoking the authority of a great, unknown in France astrologer was a proof of erudition of the Polish scholar. The idea of an universal Catholic monarchy ruled by the French king, that was beginning to materialise through the election of Henri de Valois as the king of Poland, was portrayed in countless propaganda pamphlets, medals, slogans, and occasional installations. ${ }^{46}$ The work of Solikowski, although much belated, fitted perfectly into that propaganda campaign. The prophecy, depicting Henri as a great Christian king, matched frequently published at that time texts that described disturbing phenomena: the appearance of a 'new star' in $1572^{47}$ and the great conjunction of Saturn and Jupiter in Aries, announced for 1583. According to astrological teachings, that extremely rare, occurring once for 960 years, arrangement of planets was

Museum Lutherhalle Wittenberg 1997), ed. by J.G.H. Hoppmann, Wittenberg, 1997; C. Brosseder, Im Bann der Sterne. Caspar Peucer, Philipp Melanchthon und andere Wittenberger Astrologen, Berlin, 2004.

45 Cf. Kurze, 'Prophecy and History...', op. cit., p. 74. See also, J.G.H. Hoppmann, 'The Lichtenberger Prophecy and Melanchthon's Horoscope for Luther', Culture and Cosmos, 1, 1997, 2, pp. 49-59.

46 A discussion of the imperial idea in symbolic depictions of Henri de Valois as King of Poland will be included in my doctoral thesis. Cf. E. Kociszewska, 'Astrology and Empire. A Device for the Valois King of Poland', Journal of the Warburg and the Courtauld Institutes, 73, 2011, pp. 221-55.

47 Supernova, visible on the sky in November 1572, aroused a huge interest among scholars. The appearance of a 'new star' denied the teachings of Aristotle, who claimed celestial bodies to be unchanging. Humanists and writers attributed various mystical meanings to the 'new star', also those related to the coming of a universal monarch. See F. Secret, L'ésoterisme de Guy Le Fèvre de la Boderie, Geneva, 1969, pp. 156-61; J. Céard, 'Postel et l'“étoile nouvelle” de 1572', in Guillaume Postel 1581-1981, ed. by M.L. Kuntz et al., Paris, 1985, pp. 349-56; M. Weichenhan, 'Ergo perit coelum...' Die Supernova des Jahres 1572 und die Überwindung der aristotelischen Kosmologie, Stuttgart, 2004; R. Gorris-Camos, "La stella delle maraviglie”. Un poète et une étoile, la supernova de 1572', in Esculap et Dionysos. Mélanges en l'honneur de Jean Céard, ed. by J. Dupèbe et al., Geneva, 2008, pp. 543-68. 
a harbinger of exceptional, world-transforming events ${ }^{48}$ - for example, the coming of a great, universal ruler. Such expectations were advantageous for sycophants flattering their kings. In France, naturally, a glorious future was being predicted for Henri de Valois, whose reign in Poland was to be only an introduction to the conquest of the world.

\section{APPENDIX}

Vaticinium de coniunctione Liliorum cum Aquila, desumptum ex antiquis praedictionibus Ioannus Lichtembergii, quod adscribit D. Brigittae Sveciae Regiae

Brigitta Sveciae Regina ait: Egredietur Lilium ex agro occidentali, erit crescens in mille millia in terra virginali: [24v] recuperabit amissa. Odore suo rigabit venenosa et erit fortior cedro. O Iuvenis in terra lilii attende, quod noua testa capit, inveterata sapit. Impinge tabulae cordis tui, quae huc usque rasa, ut regibus congruit: corrige conscientiam tuam et vide an sis de bono Gallo vel malo. Nam de bono Gallo prophetia invenitur ad eum modum. Aquilae grandi sociabitur lilium ab occidente in orientem et movebitur contra leonem. Leo carebit auxilio et decipietur a lilio. Fragrabit lilium in Alemania, unde laus eius suprema volabit sub Aquila. O Francia terra nobilis, quae talem fers florem, qui arborem arefactam, iam multis annis transactis, solum odoris aspersione virescere faciet. Et amore charitatis inflammabit Aquilam orientalem, volantem ad ardua alis duabus et fulgentem in montibus Christianitatis: Istud est lilium odoriferum unde apes fidelium in Ecclesia sugent mel affectionis ac desiderii: rebelles autem venenunt lamentationis. Et lilium cum aureolis stabit illaesum. Istud lilium, desiderabunt puellae Scorpionis Alemanicae nationis, ut inde suas corollas plectant propter festiuitatem, unde lugu-[25r]-briter flebunt. O iuvenis in terra lilii vide ne dicatur, Vae terrae in qua Rex puer est, cum tu sis ille qui campum Saphyri sub

48 The belief was taken from Albumasar's treatise De magnis coniunctione. See Abu Ma'sar on Historical Astrology, The Book of Religions and Dynasties (On the Great Conjunctions), ed. and transl. by C. Burnett and K. Yamamoto, Leiden, 2000; M.E. Astron, 'The Fiery Trigon Conjunction. An Elizabethan Astrological Prediction', Isis, 61, 1970, pp. 159-67. 
coelo defers, tribus aureis liliis confitum. Ideo Christianissimus vocaberis inter omnes Reges.

\section{Explicatio}

Ioannes Lichtembergius quis fuerit, eius scripta ostendunt, quae iterum atque; iterum excusa in nostris manibus versantur. Ex quibus apparet et astrorum scientiae peritissimum fuisse, cum prope omnia ad syderum vim ordinemque revocet: et in divinando faelicissimum, cum multa evenerint, quae eventura praedixit. Sumpsit et ex aliis se antiquioribus multa, ut hoc ex D. Brigittae revelationibus: quod si ii qui in republ. consilio et auctoritate valent expenderint probe, non de aliis temporibus aut principe praedicta cognoscent, quam nostris et rege communi Galliae et Poloniae, dabuntque operam, ut ne ea regna divinitus sociata separentur, quorum coniunctio utrisque populis et honorifica et salutaris, distractio exitialis et funesta procul dubio futura est. Sed iam explicationem ipsam vaticinii videamus. [25v]

\begin{tabular}{|c|c|c|c|}
\hline & Vaticinium D. Brigittae & & Explicatio \\
\hline A & $\begin{array}{l}\text { Egredietur lilium ex agro occi } \\
\text { dentali: erit crescens in mille } \\
\text { millia in terra Virginali. }\end{array}$ & A & $\begin{array}{l}\text { Egressum est in electione Sar } \\
\text { matica ae evocatum ex occidente } \\
\text { in orientem. Terram virginalem } \\
\text { puto intelligi Poloniam. Nam ut } \\
\text { virgini eligitur vir, ita illi Regno } \\
\text { Rex. }\end{array}$ \\
\hline B & Recuperabit amissa. & B & $\begin{array}{l}\text { Veterem nempe gloriam, felicita } \\
\text { tem et caetera regnorum orna- } \\
\text { menta. }\end{array}$ \\
\hline $\mathrm{C}$ & Odore suo rigabit venenosa. & $\mathrm{C}$ & $\begin{array}{l}\text { Odore virtutis suae pravas homi } \\
\text { num machinationes tollet. }\end{array}$ \\
\hline
\end{tabular}




\begin{tabular}{|c|c|c|c|}
\hline $\mathrm{D}$ & Et erit fortior cedro. & $\mathrm{D}$ & $\begin{array}{l}\text { An is non erat fortior in electio- } \\
\text { ne, pericula nulla perhorrens, } \\
\text { tam in advenda Sarmatia, quam } \\
\text { Gallia repetenda. }\end{array}$ \\
\hline $\mathrm{E}$ & $\begin{array}{l}\text { O iuvenis in terra lilii atten- } \\
\text { de, quod noua testa capit in- } \\
\text { veterata sapit. }\end{array}$ & $\mathrm{E}$ & $\begin{array}{l}\text { Iuvenem indicat et eum quidem } \\
\text { cuius teneras aetas provectione } \\
\text { res magnas pollicetur. }\end{array}$ \\
\hline $\mathrm{F}$ & $\begin{array}{l}\text { Impinge tabulae cordis tui } \\
\text { quae huc usque rasa, ut Re- } \\
\text { gibus con-[25v]-gruit, corrige } \\
\text { conscientiam tuam et vide, an } \\
\text { sis de bono Gallo vel malo. }\end{array}$ & $\mathrm{F}$ & $\begin{array}{l}\text { Cum iuventutis Regiae innocen- } \\
\text { tiam indicat, tum si ad res gegru- } \\
\text { it }[25 \mathrm{v}] \text { stas referatur, ea notat } \\
\text { quae huc usque gessit, non suo } \\
\text { sed fratris nomine. Caetera sunt } \\
\text { plana. }\end{array}$ \\
\hline G & $\begin{array}{l}\text { Nam de bono Gallo antiqua } \\
\text { prophetia invenitur, ad eum } \\
\text { modum. Aquilae grandi so- } \\
\text { ciabitur Lilium ab Occiden- } \\
\text { te in Orientem et movebitur } \\
\text { contra leonem. }\end{array}$ & G & $\begin{array}{l}\text { Lilium cum Aquila grandi socia- } \\
\text { tum est hoc tempore, Rege hoc } \\
\text { Galliae et Poloniae. Leo Turca } \\
\text { est. Neque enim hic insignia } \\
\text { spectanda sunt, sed potentia. }\end{array}$ \\
\hline $\mathrm{H}$ & $\begin{array}{l}\text { Leo carebit auxilio et decipie- } \\
\text { tur a lilio. }\end{array}$ & $\mathrm{H}$ & $\begin{array}{l}\text { Id est, queretur se desertum a li- } \\
\text { lio. }\end{array}$ \\
\hline I & $\begin{array}{l}\text { Flagrabit lilium in Alemania, } \\
\text { unde laus eius suprema vola- } \\
\text { bit sub Aquila. }\end{array}$ & I & $\begin{array}{l}\text { Hinc apparet, eam coniunctio } \\
\text { nem non intelligi de Aquila } \\
\text { Germanica. Nam post coniun- } \\
\text { ctionem cum Aquila pollicetur } \\
\text { fragrantiam in Germania et su- } \\
\text { premam laudem. }\end{array}$ \\
\hline
\end{tabular}




\begin{tabular}{|c|c|c|c|}
\hline $\mathrm{K}$ & $\begin{array}{l}\text { O Francia terra nobilis, quae } \\
\text { talem fers florem, qui arbo- } \\
\text { rem are factam iam multis } \\
\text { annis transactis, solum odo- } \\
\text { ris aspersione virescere faciet. } \\
{[26 \mathrm{v}]}\end{array}$ & $\mathrm{K}$ & $\begin{array}{l}\text { Arbor arefacta Galliam tot ma- } \\
\text { lis attritam significat. Odoris } \\
\text { aspersionem vocat famam virtu- } \\
\text { tis Regiae, quam cum sui tanti } \\
\text { apud exteros fieri viderint, magis } \\
\text { amabunt, atque ad concor-[- } \\
26 \mathrm{v}] \text {-diam reuersi, patriam revi- } \\
\text { rescere sinent. }\end{array}$ \\
\hline $\mathrm{L}$ & $\begin{array}{l}\text { Et amore charitatis inflam- } \\
\text { mabit Aquilam Orientalem. }\end{array}$ & $\mathrm{L}$ & $\begin{array}{l}\text { Amor hic se in electione osten- } \\
\text { dit, cum Aquila id est Poloni, } \\
\text { eius id est principis huius amo- } \\
\text { re inflammati, Regem summa } \\
\text { contentione deposcerunt, Aquila } \\
\text { Orientalis Polonia est. }\end{array}$ \\
\hline $\mathrm{M}$ & $\begin{array}{l}\text { Volantem ad ardua alis dua- } \\
\text { bus et fulgentem in montibus } \\
\text { Christianitatis. }\end{array}$ & $\mathrm{M}$ & $\begin{array}{l}\text { Hoc loco evolatio eius Aquilae } \\
\text { in montes Christianitatis id est } \\
\text { in regnum Galliae praedicitur. }\end{array}$ \\
\hline $\mathrm{N}$ & $\begin{array}{l}\text { Istud est lilium odoriferum } \\
\text { unde apes fidelium in Eccle- } \\
\text { sia sugent mel affectionis ac } \\
\text { desiderii, rebelles autem ve- } \\
\text { nenum lamentationis. }\end{array}$ & $\mathrm{N}$ & $\begin{array}{l}\text { Istum inquit principem fideles } \\
\text { summo amore complectentur, } \\
\text { ac eius interdum absentis deside- } \\
\text { rio tenebuntur. Rebelles autem } \\
\text { ob prosperos eius successus se } \\
\text { excruciabunt et ipsi sibi mala ac- } \\
\text { cersent, quae araneae esse quam } \\
\text { apes malint. }\end{array}$ \\
\hline $\mathrm{O}$ & $\begin{array}{l}\text { Et lilium cum aureolis stabit } \\
\text { illaesum. [27r] }\end{array}$ & $\mathrm{O}$ & $\begin{array}{l}\text { Regni, regnoque; stabilita- } \\
\text { tem policetur, per aureolos } \\
\text { Franciae gloriam et praeemi- } \\
\text { nen- }[27 \mathrm{r}] \text {-tiam ac privilegia illa } \\
\text { coelestia quae caeteris regnis ha- } \\
\text { bet, significat. }\end{array}$ \\
\hline
\end{tabular}




\begin{tabular}{|c|l|l|l|}
\hline $\mathrm{P}$ & $\begin{array}{l}\text { Istud lilium desiderabunt } \\
\text { puellae Scorpionis Alema- } \\
\text { nicae nationis, ut inde suas } \\
\text { corollas plectant propter fe- } \\
\text { stivitatem, unde lugubriter } \\
\text { flebunt. }\end{array}$ & $\mathrm{P}$ & $\begin{array}{l}\text { Desiderium Alemaniae et spem } \\
\text { de hoc rege expectationemque } \\
\text { declarat. }\end{array}$ \\
\hline $\mathrm{Q}$ & $\begin{array}{l}\text { O iuvenis in terra lilii, vide } \\
\text { ne dicatur, vae terrae in qua } \\
\text { Rex puer est, cum tu sis ille } \\
\text { qui campum saphyri sub co- } \\
\text { elo defers tribus aureis liliis } \\
\text { confitum. }\end{array}$ & $\mathrm{Q}$ & $\begin{array}{l}\text { Praemonet iuvenem ut se et Re- } \\
\text { gem esse agnoscat et quidem ta- } \\
\text { lem Regem }\end{array}$ \\
\hline $\mathrm{R}$ & $\begin{array}{l}\text { Ideo Christianissimus voca- } \\
\text { beris inter omnes Reges. }\end{array}$ & $\mathrm{R}$ & Inter suos et externos. \\
\hline
\end{tabular}

Hanc praedictionem si Henricus tertius, prius Poloniae tantum, nunc et Galliae rex, sibi ab oculos ponet et re ipsa Christianissimus id est Christi gloriae studiosissimus erit et agnoscet, haec non de alio quam se ipso praedici. Et intelliget, se non tantum $[27 \mathrm{v}]$ eo loco esse, ut Galliam et Poloniam tueri ac ornare, verum etiam de toto orbe Christiano benemereri possit, cum sempiterna nominis sui gloria et praemiis aeternis.

Esaiae 44. Ioel 2.

Faciam prophetare filios et filias vestras si servaveritis mandata mea. Translated by Kamil O. Kuraszkiewicz

First published as: 'Vaticinium de coniunctione Liliorum cum Aquila. Przepowiednia z Prognosticatio... Johanna Lichtenbergera i jej interpretacja dla Henryka Walezego (1575)', Odrodzenie i Reformacja w Polsce, 54, 2010, pp. 161-77. 